\title{
Epidermal growth factor receptor is associated with the onset of skeletal related events in non-small cell lung cancer
}

\author{
Shu-Mei Huang ${ }^{1,2}$, Jin-Ji Yang², Hua-Jun Chen², Si-Pei Wu², Xiao-Yan Baí2, Qing \\ Zhou ${ }^{2}$, Hai-Yan $\mathrm{Tu}^{2}$ and Yi-Long $\mathrm{Wu}^{1,2}$ \\ ${ }^{1}$ Southern Medical University, Guangzhou, Guangdong, P.R. China \\ ${ }^{2}$ Guangdong Lung Cancer Institute, Guangdong General Hospital \& Guangdong Academy of Medical Sciences, Guangzhou, \\ Guangdong, P.R. China \\ Correspondence to: Yi-Long Wu, email: syylwu@live.cn \\ Keywords: non-small cell lung cancer, epidermal growth factor receptor, tyrosine kinase inhibitors, bone metastasis, skeletal re- \\ lated events \\ Received: February 21, $2017 \quad$ Accepted: May 15, $2017 \quad$ Published: June 28, 2017
}

Copyright: Huang et al. This is an open-access article distributed under the terms of the Creative Commons Attribution License 3.0 (CC BY 3.0), which permits unrestricted use, distribution, and reproduction in any medium, provided the original author and source are credited.

\section{ABSTRACT}

Background : Bone metastasis and skeletal related events (SREs) are common in non-small cell lung cancer (NSCLC). Patients with mutant epidermal growth factor receptor (EGFR) could benefit from tyrosine kinase inhibitors (TKIs). However, it is unclear whether SRE is influenced by EGFR status. We aimed to evaluate the correlation of EGFR status and TKIs with the incidence of SREs.

Methods : We conducted a retrospective study of stage IV NSCLC patients with bone metastasis. Incidence rate of SREs was collected and was compared using chi-square test. Logistic-regression analysis was used to identify the risk factors predicting the incidence of SREs.

Results :410 eligible patients were enrolled in the study. 49.0\% were detected with EGFR mutation. $49.8 \%$ of patients received EGFR-TKIs therapy prior to the onset of SREs. $42.7 \%$ experienced at least one SRE. Patients who were treated with TKIs held lower incidence of SREs than patients who were not treated with TKIs $(23.5 \%$ vs $61.7 \%, p<0.001$ ). Multivariate analysis showed that poor performance status (OR $5.550,95 \%$ CI 2.290-13.450; $p<0.001$ ) and mutant EGFR (OR 3.050, 95\%CI 1.608$5.787, p=0.001$ ) were independent risk factors predicting the onset of SREs, while the usage of TKIs (OR $0.102,95 \% \mathrm{CI} 0.054-0.193, p<0.001$ ) was a protective factor of SREs in NSCLC patients with bone metastasis.

Conclusions : This study indicates that the incidence of SREs is common in both patients with and without EGFR mutation. Poor performance ability and mutant EGFR imply higher risks of SREs, while the usage of TKIs may be a protective factor of SREs.

\section{INTRODUCTION}

Bone metastasis was observed in $30 \%$ to $60 \%$ of advanced non-small cell lung cancer (NSCLC) patients [1, 2], subsequently $30 \%$ to $65 \%$ would experience at least one skeletal related event (SRE) during follow-up [2-4]. SREs were defined as pain requiring palliative radiation, bone instability requiring palliative surgery, pathological fracture, and spinal compression [1]. In clinical practice, the early diagnosis of bone metastasis and the prevention of SREs in NSCLC patients were usually overlooked, owing to a relatively short life expectancy. For patients with unknown driver gene mutation status, survival post bone metastasis was reported to be less than 6 months $[2,5]$. For patients with mutant epidermal growth factor receptor (EGFR), it was a different story. Median survival was about 3.5 years for patients with mutant EGFR and who received targeted therapy, while median survival was about 2.4 years for patients with mutant driver gene who did not received tyrosine kinase inhibitors (TKIs) [68]. For patients with mutant EGFR who received TKIs, concerns aroused whether the activity of the EGFR signal 
pathway in bone microenvironment would expedite the onset of SREs, or could TKIs therapy inhibit bone invasion and decrease the incidence of SREs. Limited studies are available to illustrate factors predicting SREs in NSCLC patients with known EGFR status [9, 10], precluding a definite conclusion. This retrospective study was to explore the correlation of EGFR status and the usage of TKIs with the incidence of SREs in NSCLC patients with bone metastasis.

\section{RESULTS}

\section{Baseline characteristics}

Among patients who were diagnosed with stage IV NSCLC from 2003 to 2012 in our institute, $63.9 \%$ of patients with mutant EGFR were detected to have bone metastasis, while $54.4 \%$ of patients with wild type EGFR were found to have bone involvement $(p=0.004) .410$ eligible patients were enrolled in our study, of whom $40.2 \%$ were female, and $60.2 \%$ were never smokers. At the time of bone metastasis, $90.5 \%$ of patients presented ECOG PS of 0 or 1 . Compared to patients with wild type EGFR, patients with mutant EGFR presented higher percentage of PS 0 or $1(95.0 \%$ vs $86.1 \%, p=0.002)$. Adenocarcinoma was the most common type of histology, consisting of $88.8 \%$, and EGFR mutation was detected in $49.0 \%$ of patients. Systemic therapy was administered to $99 \%$ of patients who were included in our study. $49.8 \%$ of patients received EGFR-TKIs prior to the onset of first SRE. For patients harboring EGFR mutation, 63.7\% received TKIs as first line treatment. Table 1 showed patient characteristics in this study.

\section{Characteristics of bone lesions and SREs}

$81.0 \%$ of patients presented bone involvement at the time of the diagnosis of NSCLC. For patients without bone involvement at initial diagnosis of advanced NSCLC, the median time to bone metastasis was 11 months $(95 \%$ confidence interval (CI) $7.4 \mathrm{~m}-14.6 \mathrm{~m}$ ). At the time of bone metastasis, $81 \%$ had multiple bone lesions and $63.7 \%$ had osteolytic lesions, which were not significantly different between patients with and without EGFR mutation ( $p$ $=0.116, p=0.149$; respectively). Bisphosphonates were given to patients according to patients' clinical manifestations. Bisphosphonates were administered in $29 \%$ of patients (zoledronic acid consisted of $28.5 \%$ ) prior to SREs, which was similar between patients with and without EGFR mutation ( $p=0.771) .52$ out of 118 patients were given at the time of bone involvement, and 66 out of 118 patients were given during follow up, when patients complained about symptoms. Patients who received bisphosphonates prophylactically confronted a lower rate of SRE comparing with patients who did not $(36.1 \%$ vs $45.4 \%, p=0.087)$. Besides, in our study, bisphosphonates were used in 41 patients after the onset of the first SRE.

Median time of follow up was 16 months. 42.7\% of patients confronted at least one SRE. For patients with EGFR mutation, the incidence rate was $37.3 \%$, which was about $10 \%$ lower than patients with wild type EGFR $(p=0.031)$. For patients who were treated with TKIs, regardless of EGFR status, 23.5\% experienced at least one SRE, while for patients without TKIs therapy, 61.7\% experienced at least one SRE $(p<0.001)$. We should notice that $13.7 \%$ of patients were initially diagnosed with NSCLC because of the occurrence of SREs, and 4.9\% were not diagnosed with bone involvement until the onset of SRE during follow up.

Palliative radiotherapy was the most common type of SRE, consisting of $50.3 \%$, and pathological fracture was the second most common type, about $30.0 \%$. The difference of manifestations of SREs was not significant between patients with and without EGFR mutation ( $p=$ 0.421 ). Table 2 showed types of SREs for patients who were included in our study.

\section{Factors predicting SREs for NSCLC patients with bone metastasis}

Table 3 showed the variables that were correlated to the onset of first SRE in NSCLC patients with bone metastasis. In univariate analysis, ECOG PS, EGFR mutation status, treatment strategies, density of bone lesions and usage of bisphosphonates were conducted with a $\mathrm{p}$ value lowered than 0.10 , thus were included in multivariate analysis. The results of multivariate analysis showed that poor PS (OR 5.550, 95\%CI 2.290-13.450; $p<$ 0.001 ) and mutant EGFR (OR 3.050, 95\%CI 1.608-5.787, $p=0.001)$ were independent risk factors predicting the onset of SREs, while the usage of TKIs (OR 0.102, 95\%CI 0.054-0.193, $p<0.001)$ was a protective factor.

Subgroup analysis of 354 patients who did not experience initial SRE at the time of NSCLC diagnosis showed that the difference of SRE incidence was not significant between patients with and without EGFR mutation (29.6\% vs $37.7 \%, p=0.107)$. In subgroup analysis, patients who were treated with TKIs presented lower incidence of SREs than patients who were not treated with TKIs did $(23.5 \%$ vs $47.3 \%, p<0.001)$. For patients who did not experience initial SRE, the usage of TKIs was a protective factor of SREs (OR $0.342,95 \%$ CI 0.217-0.540, $p<0.001)$.

\section{DISCUSSION}

For NSCLC patients who harbored sensitive EGFR mutation, TKIs tremendously improved their quality 
Table 1: Clinical characteristics of NSCLC patients with bone metastasis which were grouped by EGFR mutation status.

\begin{tabular}{|c|c|c|c|}
\hline & EGFR mutant (\%) $N=201$ & EGFR wild type (\%) $N=209$ & $p$ value \\
\hline $\begin{array}{l}\text { Gender } \\
\text { Female } \\
\text { male } \\
\end{array}$ & $\begin{array}{c}106(52.7) \\
95(47.3) \\
\end{array}$ & $\begin{array}{c}59(28.2) \\
150(71.8) \\
\end{array}$ & $<0.001$ \\
\hline $\begin{array}{l}\text { Age } \\
\text { Median (range)(year) }\end{array}$ & $\begin{array}{c}59.0 \\
(28-85) \\
\end{array}$ & $\begin{array}{c}58.0 \\
(24-86) \\
\end{array}$ & 0.325 \\
\hline $\begin{array}{l}\text { ECOG PS } \\
0,1 \\
2,3 \\
\end{array}$ & $\begin{array}{c}191(95.0) \\
10(5.0)\end{array}$ & $\begin{array}{l}180(86.1) \\
29(13.9)\end{array}$ & 0.002 \\
\hline $\begin{array}{l}\text { Smoking history } \\
\text { Nonsmoker } \\
\text { Smoker }\end{array}$ & $\begin{array}{c}152(75.6) \\
49(24.4)\end{array}$ & $\begin{array}{c}95(45.5) \\
114(54.5)\end{array}$ & $<0.001$ \\
\hline $\begin{array}{l}\text { Pathology } \\
\text { ADC } \\
\text { Others }\end{array}$ & $\begin{array}{c}196(97.5) \\
5(2.5) \\
\end{array}$ & $\begin{array}{c}168(80.4) \\
41(19.6)\end{array}$ & $<0.001$ \\
\hline $\begin{array}{l}\text { TKIs therapy } \\
\text { No } \\
\text { Yes }\end{array}$ & $\begin{array}{c}41(20.4) \\
160(79.6) \\
\end{array}$ & $\begin{array}{c}165(78.9) \\
44(21.1) \\
\end{array}$ & $<0.001$ \\
\hline $\begin{array}{l}\text { Number } \\
\text { Solitary } \\
\text { Multiple } \\
\end{array}$ & $\begin{array}{c}32(15.9) \\
169(84.1) \\
\end{array}$ & $\begin{array}{c}46(22.0) \\
163(78.0) \\
\end{array}$ & 0.116 \\
\hline $\begin{array}{l}\text { Density } \\
\text { OB } \\
\text { OC } \\
\text { Mixed type } \\
\text { NA }\end{array}$ & $\begin{array}{c}61(30.3) \\
119(59.2) \\
21(10.4) \\
- \\
\end{array}$ & $\begin{array}{c}51(24.4) \\
142(67.9) \\
15(7.2) \\
1(0.5) \\
\end{array}$ & 0.149 \\
\hline $\begin{array}{l}\text { Bisphosphonates } \\
\text { Yes } \\
\text { No }\end{array}$ & $\begin{array}{c}57(28.4) \\
144(71.6) \\
\end{array}$ & $\begin{array}{c}62(29.7) \\
147(70.3) \\
\end{array}$ & 0.771 \\
\hline $\begin{array}{l}\text { SREs } \\
\text { No } \\
\text { Yes } \\
\end{array}$ & $\begin{array}{c}126(62.7) \\
75(37.3) \\
\end{array}$ & $\begin{array}{l}109(52.2) \\
100(47.8) \\
\end{array}$ & 0.031 \\
\hline
\end{tabular}

Clinical characteristics of NSCLC patients with bone metastasis which were grouped by EGFR mutation status. EGFR, epidermal growth factor receptor; mutant EGFR was confined to exon 19 deletion and exon 21 L858R point mutation in our study; ECOG PS, Eastern Cooperative Oncology Group Performance Status; ADC, adenocarcinoma; TKIs, tyrosine kinase inhibitors, usage of TKIs was defined as usage prior to first SRE; OB, osteoblastic lesion; OC, osteolytic lesion; NA, data not available; SREs, skeletal related events; Quantitative variables were compared using student $\mathrm{T}$ test and qualitative variables were compared using chi-square test. $P$ value lowered than 0.05 at two tails was considered to be statistically significant.

of life and prolonged their life expectancy. Considering that the EGFR signal pathway was not only associated with angiogenesis [14], activating cell proliferation and epidermal mesenchymal transition in lung cancer cells [15], but also was related to bone matrix cell proliferation and differentiation [16], and that bone was a common site of distant involvement in NSCLC, we investigated bone metastasis and SREs among patients with known EGFR status. Confavreux and colleagues had reported that the incidence rate of bone metastasis was higher in EGFR-positive patients, comparing to the average rate in all stage IV NSCLC patients [17]. Our study showed that bone metastasis was more common in EGFR mutant patients than in EGFR wild type patients. We found that the distribution of bone lesions and types of SREs were similar between patients with and without EGFR mutation. With respect to performance status, patients with mutant
EGFR possessed better performance status at the time of bone presentation than patients with wild type EGFR did. The incidence rate of SREs was lower in patients who were treated with EGFR-TKIs. Poor performance status and positive EGFR mutation were independent negative factors predicting SREs. The usage of EGFR-TKIs could decrease the onset of SREs in NSCLC patients.

In our study, $49 \%$ of patients were detected with mutant EGFR, who possessed better performance ability at the time of bone metastasis. Subgroup analysis showed that was significant in patients who had bone lesions at the time of diagnosis of NSCLC $(p=0.005)$, but was not significant in patients who developed bone lesions during follow up ( $p=0.165)$ (data not shown). We assumed that, for one hand, TKIs impeded the aggressive behavior of tumor cells and thus improved the quality of life [18]. While for patients who developed bone lesions during 
Table 2: Types of first SRE in NSCLC patients.

\begin{tabular}{|l|c|c|c|}
\hline & EGFR mutant $(\%) \boldsymbol{N}=\mathbf{7 5}$ & EGFR wild type (\%) $\boldsymbol{N = 1 0 0}$ & $\boldsymbol{p}$ value \\
\hline Radiotherapy & $39(52.0)$ & $49(49.0)$ & 0.421 \\
\hline Surgery & $3(4.0)$ & $7(7.0)$ & \\
\hline Fracture & $26(34.7)$ & $28(28.0)$ & \\
\hline Compression & $7(9.3)$ & $16(16.0)$ & \\
\hline
\end{tabular}

Types of first SRE in NSCLC patients. Radiotherapy, pain requiring palliative radiation; Surgery, bone instability requiring palliative surgery; Fracture, pathological fracture; Compression, spinal compression. $P$ value was obtained using chi-square test.

Table 3: Univariate and multivariate analysis of factors predicting SREs for NSCLC patients.

\begin{tabular}{|c|c|c|c|c|c|c|}
\hline & $\begin{array}{c}\text { univariate } \\
\text { OR }\end{array}$ & $95 \% \mathrm{CI}$ & $\begin{array}{c}\text { analysis } p \\
\text { value }\end{array}$ & multivariate $\mathrm{OR}$ & $95 \% \mathrm{CI}$ & $\begin{array}{c}\text { analysis } p \\
\text { value }\end{array}$ \\
\hline $\begin{array}{l}\text { Gender } \\
\text { Female/male }\end{array}$ & 1.363 & $0.912-2.039$ & 0.131 & - & - & - \\
\hline $\begin{array}{l}\text { Age } \\
<60 y / \geq 60 y\end{array}$ & 0.899 & $0.608-1.331$ & 0.595 & - & - & - \\
\hline $\begin{array}{l}\text { ECOG PS } \\
0,1 / 2,3\end{array}$ & 6.109 & $2.732-13.660$ & $<0.001$ & 5.550 & $2.290-13.450$ & $<0.001$ \\
\hline $\begin{array}{l}\text { Smoking history } \\
\text { Nonsmoker/smoker }\end{array}$ & 1.202 & 0.806-1.792 & 0.367 & - & - & - \\
\hline $\begin{array}{l}\text { Pathology } \\
\text { ADC/others }\end{array}$ & 0.938 & $0.503-1.749$ & 0.841 & - & - & - \\
\hline \begin{tabular}{|l} 
EGFR status \\
Wild type/mutant
\end{tabular} & 0.649 & $0.437-0.962$ & 0.031 & 3.050 & $1.608-5.787$ & 0.001 \\
\hline $\begin{array}{l}\text { TKIs therapy } \\
\text { No/yes }\end{array}$ & 0.191 & $0.125-0.294$ & $<0.001$ & 0.102 & $0.054-0.193$ & $<0.001$ \\
\hline $\begin{array}{l}\text { Number } \\
\text { Solitary/multiple }\end{array}$ & 1.519 & $0.908-2.541$ & 0.111 & - & - & - \\
\hline $\begin{array}{l}\text { Quality } \\
\text { OB/OC } \\
\text { OB/mixed type }\end{array}$ & $\begin{array}{l}2.208 \\
1.297 \\
\end{array}$ & $\begin{array}{l}1.380-3.533 \\
0.588-2.858 \\
\end{array}$ & $\begin{array}{l}0.003 \\
0.001 \\
0.519 \\
\end{array}$ & $\begin{array}{l}1.629 \\
1.097 \\
\end{array}$ & $\begin{array}{l}0.970-2.737 \\
0.451-2.668\end{array}$ & $\begin{array}{l}0.150 \\
0.065 \\
0.838 \\
\end{array}$ \\
\hline $\begin{array}{l}\text { Bisphosphonate } \\
\text { Yes/no }\end{array}$ & 1.467 & $0.945-2.277$ & 0.087 & 0.923 & $0.553-1.541$ & 0.761 \\
\hline
\end{tabular}

410 patients were included in the analysis. Factors with a $p$ value lower than 0.10 in univariate analysis were included in multivariate analysis. In multivariate analysis, factors with a $p$ value lower than 0.05 were considered independent risk factors predicting SRE. Poor PS and mutant EGFR were considered as independent risk factors predicting SREs in NSCLC patients, while the usage of EGFR-TKIs was considered as a protective factor of SRE in NSCLC patients with bone metastasis. Logistic regression model was conducted to analyzed potential factors predicting SREs.

follow up, the appearance of bone lesions indicated that tumor cells developed resistance to targeted drugs and progressed aggressively.

Recently, the characteristics of isolated bone failure (IBF) without progression in extraskeletal organs in EGFR mutation patients were evaluated by Hwang and colleagues [19]. They found that IBF were more frequently detected in patients who responded to EGFRTKIs compared to those without clinical benefit $(54.4 \%$ $\left.v_{s} 14.3 \%, p=0.007\right)$, in patients with good performance ability $(82.5 \%$ vs $42.9 \%, p=0.005)$, and in patients with exon 19 deletion $(68.4 \%$ vs $35.7 \%, p=0.024)$. And clinical benefit from EGFR-TKIs was the independent risk factor predicting IBF (OR 6.647, 95\% CI 1.328-33.262, $p$ $=0.021)$. Their results indicated that patients with IBF tended to have longer survival. The results revealed from their data and this study implied that EGFR-TKIs might affect the bone lesions separately from lesions in other organs, which awaited more findings to identify the possibility.

We then evaluated the difference of SREs in patients with known EGFR status. It revealed that mutant EGFR independently indicated higher risk of SREs, while the administration of EGFR-TKIs, regardless in mutant or wild type patients, was a protective factor of SREs. Several studies have previously analyzed the correlation. Aiba and colleagues analyzed 47 patients who were diagnosed with NSCLC with bone lesions in spinal column, among which 41 patients were detected with known EGFR status. Patients with EGFR mutation intended to have a lower risk to experience SREs comparing to patients without EGFR mutation (OR 0.61, 95\%CI 0.38-0.99) [12]. Sun and 
Table 4: Summary of the studies of relatively large studies that evaluated the correlation of EGFR and TKIs with SREs in NSCLC patients.

\begin{tabular}{|c|c|c|c|c|c|}
\hline Author & Type & $N$ & Incidence of SRE & Risk of SREs (EGFR) & $\begin{array}{ll}\text { Risk of } \\
\text { (EGFR-TKIs) }\end{array}$ \\
\hline Huang & $\begin{array}{l}\text { Retrospective } \\
\text { China }\end{array}$ & $\begin{array}{c}410 \\
201(\text { EGFR }+ \text { ) } \\
209 \text { (EGFR wt) }\end{array}$ & $\begin{array}{l}37.3 \% \\
47.8 \%\end{array}$ & $\begin{array}{c}\text { OR 3.050 } \\
(95 \% \text { CI } 1.608-5.787) \\
p=0.001\end{array}$ & $\begin{array}{c}\text { OR } 0.102 \\
(95 \% \text { CI } 0.054-0.193) \\
p<0.001\end{array}$ \\
\hline Hendriks [11] & $\begin{array}{l}\text { Retrospective } \\
\text { Netherlands }\end{array}$ & $\begin{array}{c}102 \\
37(\text { EGFR }+) \\
\text { 34(KRAS+) } \\
\text { 31(WT) }\end{array}$ & $\begin{array}{l}51.4 \% \\
64.7 \% \\
48.4 \%\end{array}$ & & \\
\hline Aiba [12] & $\begin{array}{l}\text { Retrospective } \\
\text { Japan }\end{array}$ & $\begin{array}{c}41 \\
17(\mathrm{EGFR}+) \\
24(\mathrm{wt})\end{array}$ & $\begin{array}{l}17.6 \% \\
45.8 \%\end{array}$ & $\begin{array}{c}\text { OR } 0.61 \\
(95 \% \text { CI } 0.38-0.99) \\
p=0.060\end{array}$ & $\begin{array}{c}\text { OR } 0.88 \\
(95 \% \text { CI } 0.48-1.60) \\
p=0.680\end{array}$ \\
\hline Sun [9] & $\begin{array}{l}\text { Retrospective } \\
\text { Korea }\end{array}$ & 273 & $62.6 \%$ & & $\begin{array}{c}\text { OR } 0.64 \\
(95 \% \text { CI } 0.35-1.18) \\
p=0.16\end{array}$ \\
\hline Katakami [13] & $\begin{array}{l}\text { Prospective } \\
\text { Japan }\end{array}$ & 59 & $33.9 \%$ & & $\begin{array}{c}\text { HR } 0.75 \\
(95 \% \text { CI } 0.27-2.04) \\
p=0.569\end{array}$ \\
\hline
\end{tabular}

Summary of the studies of relatively large studies that evaluated the correlation of EGFR and TKIs with SREs in NSCLC. EGFR +, EGFR mutation; wt, EGFR wild type; KARS +, KRAS mutation; WT, both EGFR and KRAS wild type; N, NSCLC patients with bone metastasis were included; CI, confidence interval.

colleagues reported that smokers, nonadenocarcinoma, poor performance status (ECOG PS $\geq 2$ ), and no history of EGFR TKIs therapy were independent risk factors of development of SREs throughout the course of disease [9]. In a prospective study, however, risk of SREs was not significantly associated with the history of EGFRTKIs therapy [13]. Summary of studies of relatively large studies that evaluated the correlation of EGFR and TKIs with SREs was shown in Table 4. We should notify that in these studies, the sample size was relatively small, and that the EGFR mutation status was not detected in most patients who were treated with EGFR-TKIs. The results cannot be widely applied. The result of this study, however, indicated that mutant EGFR in lung cancer cells prompted the destruction of bone lesions, leading to higher risk of SREs. However, a history of TKIs therapy disrupted the interaction, generating lower incidence of SREs. Several aspects support our hypothesis. As we has discussed before that EGFR mutant patients possessed better performance status would be a partial explanation. Also, the interaction of EGFR signaling pathway and TKIs in both tumor cells and bone matrix cells was salient.

In the bone microenvironment, active EGFR signal pathway in tumor cells was associated with angiogenesis and cell proliferation. Tumor cells could impair bone matrix directly. In addition, the EGFR signal pathway could disrupt the balance of bone matrix cells indirectly. Studies showed that the EGFR network was vital in bone biology [16]. EGFR signal pathway promoted the mesenchymal cells to differentiate into osteoclasts, activated the osteoclasts, thus accelerated bone absorption. These could partially explain why mutant EGFR in lung cancer indicated higher risk of SREs.
On the other hand, EGFR-TKIs were reported to inhibit both tumor cells and the crosstalk between tumor cells and bone matrix cells [20]. It was demonstrated by several studies that TKIs disrupted the interaction between tumor cells and mesenchymal stem cells and osteoclastic cells. Furugaki and colleagues validated that erlotinib inhibited osteolytic bone invasion which was induced by human NSCLC cell line NCI-H292 (EGFR wild type cell line) in SCID mice [21]. They found that the expression level of receptor activator of NF- $\mathrm{\kappa B}$ ligand (RANKL) was decreased to the basal level of the nontumor bearing mouse, and the activation of osteoclastic cells was decreased after adding erlotinib. Unfortunately, the influence of EGFR mutant NSCLC tumor cells imposed on the bone niches was not clear in this study, as the HCC827 NSCLC cell line (EGFR mutant cell line) bone metastatic model was not established. Garfield indicated that TKIs could decrease the secretion of growth factor and RANKL, and thus induced the differentiation of osteoblast and inhibited the proliferation and activity of osteoclast $[22,23]$. Similar results were shown in SCLC cell lines [24] and prostate cancer cell lines [25].

Interestingly, clinical practice had witnessed the result of crosstalk interruption. Osteoblastic flare was reported in patients who were treated with EGFR TKIs [26-28], which represented as a healing response of the osteolytic lesions or appearance of osteoblastic lesions while lesions in other sites were well controlled. These data revealed that TKIs could inhibit the activity of osteoclasts and activate the osteoblast, thus could interrupt the vicious cycle of tumor cells and bone matrix cells in the microenvironment, and decreased the risk of SREs. In our institute, as the relevant data was not required 
to collect during follow up, the proportion of healing response was not available in our study.

To integrate, we found that SREs were common in both patients with and without EGFR mutation. Positive prophylactic process is recommended to impose on patients with high risks to experience SREs, and to reduce the occurrence of SREs. To EGFR mutant patients, EGFRTKI is recommended as first line therapy. Combined with our results, it implies that patients with bone metastasis who would receive TKIs would hold lower risks of SREs compared to patients who would not.

Our study has limitations. First of all, it is a retrospective study in nature. Secondary, as patients included in this study were extracted from a single institute, the probably existing Berkson bias limits the application of the results to the nationwide population. The diagnostic methods of bone involvement were not standardized. However, each method exposes its limitation. In clinical practice, bone screening was not required until patients presenting with bone pain or SREs during follow up [1]. In our study, EGFR mutation was constrained to EGFR exon 19 deletion and exon 21 L858R point mutation, while patients with EGFR uncommon mutation and driver gene mutations other than EGFR were not considered in the study. Further studies focusing on these driver gene mutations are needed.

\section{CONCLUSIONS}

This study indicates that SREs are common in NSCLC patients with and without EGFR mutation. Poor performance ability and mutant EGFR imply higher risks of SREs, while the usage of TKIs may be a protective factor of SREs.

\section{MATERIALS AND METHODS}

\section{Patients}

We retrospectively reviewed clinic-pathological data of consecutive patients who were diagnosed with stage IV NSCLC with bone metastasis in Guangdong General Hospital from 2003 January $1^{\text {st }}$ to 2012 December $31^{\text {st }}$.

Patients would be included in this study if they fulfilled the following criteria, histology of NSCLC was confirmed pathologically or cytologically based on 2004 World Health Organization (WHO) classification of lung cancer [29], and the new adenocarcinoma classification [30]; known EGFR mutation status was detected by a polymerase chain reaction (PCR) based direct sequencing (SANGER sequencing) method [31] or amplification refractory mutation system (ARMS) [32] (sensitive mutation was defined as exon 19 deletion or exon 21 L858R point mutation); bone involvement was confirmed by at least one of the following methods, magnetic resonance image (MRI), bone marrow scintigraphy (ECT), positron emission tomography (PET), computed tomography (CT), X-ray, or biopsy [33, 34].

Patients would be excluded if they encountered one or more of the followings, diagnosis of secondary primary carcinoma within 2 years of the diagnosis of NSCLC; mutation of driver genes other than EGFR was detected, such as ALK, c-MET, ROS-1, KRAS.

Data of evaluated variables, including gender, age, smoking history, Eastern Cooperative Oncology Group Performance Status (ECOG PS), histology, EGFR mutation status, number and density of bone metastasis, usage of bisphosphonates, time to bone metastasis, SREs types, and treatment strategy prior to SREs, were collected and analyzed.

\section{Ethic statement}

The study was approved by the institutional review boards of Guangdong General Hospital. Furthermore, a written consent was deemed unnecessary because the data was retrospectively reviewed, and the treatment strategy was not influenced by this study.

\section{Statistics}

Descriptive statistics were conducted to analyze demographic variables and incidence of SREs. Clinicalpathological parameters were estimated as possible factors to predict incidence of SREs using a logistic regression model. Patients without a documented date of events were censored at the date of death or date of last follow-up. Parameters with a $\mathrm{p}$ value lowered than 0.10 in univariate analysis were included in multivariate analysis. $\mathrm{P}$ value lowered than 0.05 at two tails was considered of statistical significance. All statistics were analyzed by SPSS (IMB statistics, version 20.0).

\section{Abbreviations}

NSCLC, non-small cell lung cancer; EGFR, epidermal growth factor receptor; TKIs, tyrosine kinase inhibitors, SREs, skeletal related events; ECOG PS, Eastern Cooperative Oncology Group Performance Status; OB, osteoblastic; OC, osteolytic; ALK, anaplastic lymphoma kinase; RANKL, receptor activator of nuclear factor kappa-B ligand; OR, odd ratio; HR, hazard ratio; $\mathrm{CI}$, confidence interval; vs, versus.

\section{Author contributions}

Shu-Mei Huang was involved in the study design, data collection, statistical analysis and paper writing. Jin- 
Ji Yang, Hua-Jun Chen and Si-Pei Wu made substantial contributions in designing the study and modifying the manuscript. Xiao-Yan Bai was involved in the data collection, data analysis. Qing-Zhou and Hai-Yan Tu contributed to the conception and design of the study. YiLong $\mathrm{Wu}$ approved the final version of the manuscript.

\section{ACKNOWLEDGMENTS}

The authors thank Hong-Hong Yan for her statistical assistance in the data analysis process. The authors thank Chao-Wen Huang for his helpful suggestion.

\section{CONFLICTS OF INTEREST}

The authors declare no potential conflicts of interest.

\section{GRANT SUPPORT}

This research was supported by Special Fund for Research in the Public Interest from National Health and Family Planning Commission of PRC (Grant No.201402031) and Project of National Natural Science Foundation (Grant No.81272618).

\section{REFERENCES}

1. Brodowicz T, O'Byrne K, Manegold C. Bone matters in lung cancer. Annals of oncology. 2012; 23:2215-2222.

2. Santini D, Barni S, Intagliata S, Falcone A, Ferrau F, Galetta D, Moscetti L, La Verde N, Ibrahim T, Petrelli F, Vasile E, Ginocchi L, Ottaviani D, et al. Natural History of Non-Small-Cell Lung Cancer with Bone Metastases. Scientific reports. 2015; 5:18670.

3. Cetin K, Christiansen CF, Jacobsen JB, Norgaard M, Sorensen HT. Bone metastasis, skeletal-related events, and mortality in lung cancer patients: a Danish population-based cohort study. Lung cancer. 2014; 86:247-254.

4. da Silva GT, Bergmann A, Thuler LC. Skeletal related events in patients with bone metastasis arising from nonsmall cell lung cancer. Supportive care in cancer. 2016; 24:731-736.

5. Bae HM, Lee SH, Kim TM, Kim DW, Yang SC, Wu HG, Kim YW, Heo DS. Prognostic factors for non-small cell lung cancer with bone metastasis at the time of diagnosis. Lung cancer. 2012; 77:572-577.

6. Fukuoka M, Wu YL, Thongprasert S, Sunpaweravong P, Leong SS, Sriuranpong V, Chao TY, Nakagawa K, Chu DT, Saijo N, Duffield EL, Rukazenkov Y, Speake G, et al. Biomarker analyses and final overall survival results from a phase III, randomized, open-label, first-line study of gefitinib versus carboplatin/paclitaxel in clinically selected patients with advanced non-small-cell lung cancer in Asia (IPASS). Journal of clinical oncology. 2011; 29:2866-2874.
7. Mok TS, Wu YL, Thongprasert S, Yang CH, Chu DT, Saijo N, Sunpaweravong P, Han B, Margono B, Ichinose Y, Nishiwaki Y, Ohe Y, Yang JJ, et al. Gefitinib or carboplatin-paclitaxel in pulmonary adenocarcinoma. The New England journal of medicine. 2009; 361:947-957.

8. Kris MG, Johnson BE, Berry LD, Kwiatkowski DJ, Iafrate AJ, Wistuba II, Varella-Garcia M, Franklin WA, Aronson SL, Su PF, Shyr Y, Camidge DR, Sequist LV, et al. Using multiplexed assays of oncogenic drivers in lung cancers to select targeted drugs. Jama. 2014; 311:1998-2006.

9. Sun JM, Ahn JS, Lee S, Kim JA, Lee J, Park YH, Park HC, Ahn MJ, Ahn YC, Park K. Predictors of skeletal-related events in non-small cell lung cancer patients with bone metastases. Lung cancer. 2011; 71:89-93.

10. Sekine I, Nokihara H, Yamamoto N, Kunitoh H, Ohe Y, Tamura T. Risk factors for skeletal-related events in patients with non-small cell lung cancer treated by chemotherapy. Lung cancer. 2009; 65:219-222.

11. Hendriks LE, Smit EF, Vosse BA, Mellema WW, Heideman DA, Bootsma GP, Westenend M, Pitz C, de Vries GJ, Houben R, Grunberg K, Bendek M, Speel EJ, et al. EGFR mutated non-small cell lung cancer patients: more prone to development of bone and brain metastases? Lung cancer. 2014; 84:86-91.

12. Aiba H, Kimura T, Yamagami T, Watanabe N, Sakurai H, Kimura H, Shimozaki S, Yamada S, Otsuka T. Prediction of skeletal-related events in patients with non-small cell lung cancer. Supportive care in cancer. 2016; 24:3361-3367.

13. Katakami N, Kunikane H, Takeda K, Takayama K, Sawa T, Saito H, Harada M, Yokota S, Ando K, Saito Y, Yokota I, Ohashi Y, Eguchi K. Prospective study on the incidence of bone metastasis (BM) and skeletal-related events (SREs) in patients (pts) with stage IIIB and IV lung cancer-CSP-HOR 13. Journal of thoracic oncology. 2014; 9:231-238.

14. Larsen AK, Ouaret D, El Ouadrani K, Petitprez A. Targeting EGFR and VEGF(R) pathway cross-talk in tumor survival and angiogenesis. Pharmacology \& therapeutics. 2011; 131:80-90.

15. Barr S, Thomson S, Buck E, Russo S, Petti F, Sujka-Kwok I, Eyzaguirre A, Rosenfeld-Franklin M, Gibson NW, Miglarese M, Epstein D, Iwata KK, Haley JD. Bypassing cellular EGF receptor dependence through epithelial-tomesenchymal-like transitions. Clinical \& experimental metastasis. 2008; 25:685-693.

16. Schneider MR, Sibilia M, Erben RG. The EGFR network in bone biology and pathology. Trends in endocrinology and metabolism. 2009; 20:517-524.

17. Confavreux CB, Girard N, Pialat JB, Bringuier PP, Devouassoux-Shisheboran M, Rousseau JC, Isaac S, Thivolet-Bejui F, Clezardin P, Brevet M. Mutational profiling of bone metastases from lung adenocarcinoma: results of a prospective study (POUMOS-TEC). Bonekey Rep. 2014; 3:580.

18. Mok T, Yang JJ, Lam KC. Treating patients with EGFR- 
sensitizing mutations: first line or second line--is there a difference? Journal of clinical oncology. 2013; 31:10811088.

19. Hwang JA, Lee JY, Kim WS, Song JS, Rho JK, Choi CM, Lee JC. Clinical Implications of Isolated Bone Failure Without Systemic Disease Progression During EGFR-TKI Treatment. Clinical lung cancer. 2016; 17:573-580 e571.

20. Normanno N, De Luca A, Aldinucci D, Maiello MR, Mancino M, D'Antonio A, De Filippi R, Pinto A. Gefitinib inhibits the ability of human bone marrow stromal cells to induce osteoclast differentiation: implications for the pathogenesis and treatment of bone metastasis. Endocrinerelated cancer. 2005; 12:471-482.

21. Furugaki K, Moriya Y, Iwai T, Yorozu K, Yanagisawa M, Kondoh K, Fujimoto-Ohuchi K, Mori K. Erlotinib inhibits osteolytic bone invasion of human non-small-cell lung cancer cell line NCI-H292. Clinical \& experimental metastasis. 2011; 28:649-659.

22. Garfield D, Cadranel J, Normanno N. Osteoblastic metastases in non-small cell lung cancer and its possible significance. Lung cancer. 2008; 60:146-147.

23. Garfield D, Normanno N. Osteoblastosis, activating epidermal growth factor receptor mutations: a relationship? Journal of thoracic oncology. 2010; 5:415-416.

24. Gabr AG, Goto H, Hanibuchi M, Ogawa H, Kuramoto T, Suzuki M, Saijo A, Kakiuchi S, Trung VT, Sakaguchi S, Moriya Y, Sone S, Nishioka Y. Erlotinib prevents experimental metastases of human small cell lung cancer cells with no epidermal growth factor receptor expression. Clinical \& experimental metastasis. 2012; 29:207-216.

25. Borghese C, Cattaruzza L, Pivetta E, Normanno N, De Luca A, Mazzucato M, Celegato M, Colombatti A, Aldinucci D. Gefitinib inhibits the cross-talk between mesenchymal stem cells and prostate cancer cells leading to tumor cell proliferation and inhibition of docetaxel activity. Journal of cellular biochemistry. 2013; 114:1135-1144.

26. Lind JS, Postmus PE, Smit EF. Osteoblastic bone lesions developing during treatment with erlotinib indicate major response in patients with non-small cell lung cancer: a brief report. Journal of thoracic oncology. 2010; 5:554-557.

27. Pluquet E, Cadranel J, Legendre A, Faller MB, Souquet PJ, Zalcman G, Perol M, Fraboulet G, Oliveiro G, De Fraipont F, Quoix E, Lantuejoul S, Milleron B, et al. Osteoblastic reaction in non-small cell lung carcinoma and its association to epidermal growth factor receptor tyrosine kinase inhibitors response and prolonged survival. Journal of thoracic oncology. 2010; 5:491-496.
28. Ansen S, Bangard C, Querings S, Gabler F, Scheffler M, Seidel D, Saal B, Zander T, Nogova L, Topelt K, Markert E, Stoelben E, Ernestus K, et al. Osteoblastic response in patients with non-small cell lung cancer with activating EGFR Mutations and bone metastases during treatment with EGFR kinase inhibitors. Journal of thoracic oncology 2010; 5:407-409.

29. Beasley MB, Brambilla E, Travis WD. The 2004 World Health Organization classification of lung tumors. Seminars in roentgenology. 2005; 40:90-97.

30. Travis WD. Pathology of lung cancer. Clinics in chest medicine. 2011; 32:669-692.

31. Lynch TJ, Bell DW, Sordella R, Gurubhagavatula S, Okimoto RA, Brannigan BW, Harris PL, Haserlat SM, Supko JG, Haluska FG, Louis DN, Christiani DC, Settleman $\mathrm{J}$, et al. Activating mutations in the epidermal growth factor receptor underlying responsiveness of non-small-cell lung cancer to gefitinib. The New England journal of medicine. 2004; 350:2129-2139.

32. Zhou Q, Zhang XC, Chen ZH, Yin XL, Yang JJ, Xu CR, Yan HH, Chen HJ, Su J, Zhong WZ, Yang XN, An SJ, Wang BC, et al. Relative abundance of EGFR mutations predicts benefit from gefitinib treatment for advanced nonsmall-cell lung cancer. Journal of clinical oncology. 2011; 29:3316-3321.

33. Cassinello Espinosa J, Gonzalez Del Alba Baamonde A, Rivera Herrero F, Holgado Martin E, SEMO (Spanish Society of Clinical Oncology). SEOM guidelines for the treatment of bone metastases from solid tumours. Clinical \& translational oncology. 2012; 14:505-511.

34. Gravalos C, Rodriguez C, Sabino A, Segui MA, Virizuela JA, Carmona A, Cassinello J, Isla D, Jara C, Martin M. SEOM Clinical Guideline for bone metastases from solid tumours (2016). Clinical \& translational oncology. 2016; 18:1243-1253. 